\section{Szanowne Koleżanki i Koledzy, Drodzy Czytelnicy,}

Pełni nowych sił z ostatnimi miłymi wspomnieniami upalnego lata wracamy do naszej pracy. To co „nowe” zawsze jest inspirujące. Już w pierwszym tegorocznym numerze „Endokrynologii Polskiej” wspominałam Państwu o zmianach w Radzie Naukowej i Redakcyjnej naszego pisma. Dotychczasowy Przewodniczący Pan Profesor Janusz Nauman postanowił przekazać swoje obowiązki i Jego funkcję objął Profesor Marek Bolanowski, który będzie teraz kierował pracą Nowej Rady Naukowej. Ze smutkiem przyjęliśmy decyzję Pana Profesora Naumana, jednak wiemy, że zawsze możemy na Niego liczyć. Za tak wielkie zaangażowanie w pracę nad „Endokrynologią Polską” trudno jest wyrazić słowami naszą ogromną wdzięczność. Zarówno Panu Profesorowi, jak i całej dotychczasowej Radzie Naukowej EP składamy najgorętsze podziękowania. To dzięki Waszym staraniom i Waszej pracy nasze pismo po raz pierwszy w swojej ponad 60-letniej historii uzyskało Impact Factor. Stałe podnoszenie poziomu naukowego naszego pisma było i będzie nadal priorytetem w pracach Nowej Rady Naukowej. Życzymy Jej owocnej, pełnej sukcesów pracy, która sprawi, że nasze pismo będzie coraz lepsze. Wchodzi również w użytkowanie nasza nowa strona internetowa elektronicznej obsługi manuskryptów — mam nadzieje, że będzie nam lepiej służyła od dotychczasowej.

Tymczasem zachęcamy do lektury Prac oryginalnych aktualnego numeru. Wiedza o zaburzeniach endokrynnych powstających w przebiegu klinicznym chorób pozaendokrynologicznych nawet dla doświadczonych endokrynologów jest czasem zaskakująca. Celem pracy naukowców z Collegium Medicum Uniwersytetu Jagiellońskiego i prof. Mariusza Z. Ratajczaka z Uniwersytetu w Louisville była ocena aktywności układu RANKL-osteoprotegeryna, IGF-1 i interleukin-6 i 1 oraz ich korelacji z gęstością mineralną kości u dzieci i młodzieży po przeszczepieniu komórek krwiotwórczych. Po przeszczepieniu tych komórek dość często obserwuje się bowiem zaburzenia kostne. Ich dokładna etiopatogeneza pozostaje jednak wciąż nieznana, szczególnie u pacjentów po przeszczepie przebytym w dzieciństwie. Autorzy wy- kazali ujemne wartości Z-score dla BMD u wszystkich pacjentów i były one wyższe u tych po przeszczepie autologicznym niż po przeszczepie allogenicznym. Autorzy wykazali również zaangażowanie w proces przebudowy kości wszystkich badanych substancji biologicznych i prognozują, że surowicze stężenia RANKL i IGF-1 mogą być markerami metabolizmu kostnego u pacjentów po przeszczepieniu komórek krwiotwórczych.

W kolejnej pracy Autorki z Timisoary, na podstawie przeprowadzonych badań prowadzą rozważania na temat aspektów klinicznych, ultrasonograficznych i histopatologicznych choroby Hashimoto współistniejącej ze złośliwymi i łagodnymi guzkami tarczycy. Inspiracją do tego badania był znany z piśmiennictwa temat rozpowszechnienia przewlekłego autoimmunologicznego zapalenia tarczycy związanego ze zróżnicowanym rakiem tarczycy.

Zespół endokrynologów z Białegostoku w oparciu o wyniki badań własnych krytycznie analizuje i prowadzi porównanie przydatności klinicznej oznaczeń kortyzolu w ślinie i w surowicy w diagnostyce hiperkortyzolizmu. Uzyskane wyniki wskazują, że w diagnostyce subklinicznego zespołu Cushinga oznaczenie późnowieczornego stężenia kortyzolu w ślinie jest bardziej przydatne niż oznaczenie kortyzolu w surowicy o godzinie 23. Późnowieczorne stężenie kortyzolu w ślinie wydaje się również być wartościowym kryterium diagnostycznym $\mathrm{w}$ różnicowaniu rzekomego zespołu Cushinga.

W następnej publikacji oryginalnej zespół trzech profesorów z Łodzi przeprowadził immunohistochemiczną detekcję receptorów folitropiny (FSHR) w guzach neuroendokrynnych. Dotychczas wiadomo było, że ekspresja FSHR występuje w gonadach i wywodzących się z gonad nowotworach. Ostatnio jednak wykazano ich obecność także w nowotworach endokrynnych, takich jak guzy nadnerczy i gruczolaki przysadki. W obecnej pracy wykazano obecność FSHR zarówno w komórkach nowotworowych, jak i niektórych wewnątrzguzowych naczyniach krwionośnych guzów neuroendokrynnych (NETs). Dodatni odczyn 
z przeciwciałem anty-FSHR stwierdzono w cytoplazmie większości komórek badanych NETs. U połowy badanych NETs odnotowano także immunopozytywność dla FSHR w śródbłonkach wewnątrzguzowych naczyń krwionośnych. Co interesujące, dodatni odczyn dla FSHR obserwowano częściej w naczyniach krwionośnych nowotworów z wyższym indeksem Ki-67.

Kolejni Autorzy porównali surowicze stężenia prohepcydyny i parametrów metabolizmu żelaza u osób w podeszłym wieku z otyłością oraz bez otyłości. Obecny stan wiedzy wskazuje bowiem na ścisły związek pomiędzy nadwagą i otyłością a zaburzeniami metabolizmu żelaza, a hepcydyna może być istotnym czynnikiem niedoborów żelaza obserwowanych w populacji osób otyłych. Uzyskane wyniki badań potwierdziły założenie pracy. W grupie pacjentów otyłych zarówno z niedokrwistością, jak i bez niedokrwistości surowicza prohepcydyna pozytywnie korelowała z procentową zawartością tkanki tłuszczowej, co wskazuje, że tkanka tłuszczowa może mieć wpływ na stężenie surowiczej prohepcydyny, a tym samym również na ogólnoustrojową homeostazę żelaza.

Autorzy z Iranu przedstawili wyniki badania CASPIAN III oceniającego wynik oceny trafności ciągłego wskaźnika zespołu metabolicznego (cMetS) jako wskaźnika obecności zespołu metabolicznego przeprowadzonej w ogólnokrajowej próbie reprezentatywnej populacji pediatrycznej, którą było ponad 3 tysiące uczniów. Wskaźnik cMetS wydaje się być odpowiednim wskaźnikiem do zastosowania w badaniach epidemiologicznych nad związkiem między czynnikami ryzyka a występowaniem zespołu metabolicznego.

Autorzy z Azji Mniejszej ustalili rozpowszechnienia zmienności liczby kopii genów KAL1, GNRH1, GNRHR, PROK2 i PROKR2 u pacjentów płci męskiej z idiopatycznym hipogonadyzmem hipogonadotropowym (IHH). Określanie podłoża genetycznego ma ogromne znaczenie dla pogłębiania wiedzy na temat tej złożonej choroby i może być przydatne w poradnictwie genetycznym i ustalaniu leczenia. Ponadto odkrywanie powiązań pomiędzy mutacjami genetycznymi a IHH ma duże znaczenie dla pogłębiania wiedzy na temat prawidłowego funkcjonowania układu rozrodczego.

Kolejni autorzy analizowali ilość łożyskowego hormonu wzrostu (PGH), przysadkowego hormonu wzrostu (GH), IGF-1 i grehliny w surowicy krwi pępowinowej oraz w płynie owodniowym. Poszukiwali w ten sposób czynników, które pozwoliłyby na prognozowanie rozwoju noworodka. Badania te wskazały na istotną rolę PGH w utrzymaniu odpowiedniej puli IGF-1.

W dziale Prac poglqdowych zapraszamy do lektury niezwykle ciekawej pracy autorstwa endokrynologów doświadczalnych z Ohio University. Dokonano w niej przeglądu dotychczasowej wiedzy na temat wiązań di siarczkowych w strukturze hormonu wzrostu. Zagadnienie to jest ważne z punktu widzenia aktywności biologicznej GH, zarówno u osób zdrowych, jak i z mutacjami genu GH1.

Opis przypadku to tym razem doniesienie ze śląskiego ośrodka diabetologicznego. Autorzy opisują trzy kobiety pochodzące z tej samej rodziny, z rozpoznaniem rodzinnej, częściowej lipodystrofii typu Dunnigana, a więc schorzenia, z którym możemy spotkać się w swojej praktyce klinicznej bardzo rzadko. W artykule szczegółowo omówiono etiopatogenezę, przebieg kliniczny oraz diagnostykę i postępowanie — ma on więc również wybitny walor dydaktyczny.

Rozdział Szkolenie podyplomowe zawiera dwie prace. Pierwsza, autorstwa Kolegów z Warszawy poświęcona jest tym razem szerokiemu omówieniu klinicznych aspektów hiperaldosteronizmu pierwotnego, ze szczególnym zwróceniem uwagi na postępy w diagnostyce i leczeniu. W drugiej, wieloośrodkowej, międzynarodowej pracy prezentujemy aktualne wytyczne dotyczące suplementacji witaminą D adresowane do krajów Europy Środkowej. Autorzy rekomendują stosowanie określonych dawek witaminy D, zarówno w populacji zdrowej, jak i w grupach ryzyka deficytu tej witaminy.

Życzymy Państwu wielu naukowych wrażeń i praktycznych korzyści z aktualnego numeru naszego pisma.

W imieniu Redakcji Beata Kos-Kudła 


\section{Dear Colleagues and Readers,}

Welcome back, hopefully full of energy and with some nice memories of this year's hot summer! New events are always inspirational. In this year's first issue of the Endokrynologia Polska, I already mentioned some changes in the Editorial Board of our Journal. Professor Janusz Nauman decided to resign as Chairman of the Editorial Board and his duties have now been taken over by Professor Marek Bolanowski. We accepted Prof. Nauman's decision with sadness, although we know that we can still count on him. We would like to take this opportunity to express our sincere gratitude to Prof. Nauman and to the all the members of the Editorial Board working under his direction for your great commitment. Thanks to your efforts and work our Journal received its first impact factor in over 60 years of its history. Continuous improvement of the Journal's scientific quality will continue to be a priority among the tasks of the new Editorial Board. We wish the new Editorial Board fruitful and successful efforts that will make our Journal better and better. We have also launched our new Electronic Manuscript Service. We hope it will serve your needs better than the previous version.

And now a few words about what you will find in the Original papers section of this issue of the Endokrynologia Polska. The knowledge about the endocrine disorders developing in the clinical course of non-endocrine disorders can be surprising even for experienced endocrinologists. Researchers from the Jagiellonian University Medical College and Prof. Mariusz Z. Ratajczak from the University of Louisville, USA, conducted a study to assess the activity of the RANKL/osteoprotegerin system, IGF-1 and interleukin- 6 and $-1 \beta$ and their correlation with bone mineral density in children and adolescents undergoing haematopoietic stem cell transplantation (HSCT). Bone disorders are quite commonly observed after transplantation of these cells. The aetiology and pathogenesis of these disorders is, however, unclear, particularly in patients who underwent HSCT in childhood. The authors showed negative Z-score values for BMD in all the patients with higher values after autologous HSCT than after allogenic HSCT. The authors also demonstrated involvement of all the investigated biological substances in bone remodelling and believe that serum levels of RANKL and IGF-1 may serve as bone markers in post-HSCT patients.

The next paper, authored by researchers from Timisoara, Romania, discusses their original study in which they assessed clinical, sonographic and histopathologic aspects of Hashimoto's thyroiditis coexisting with malignant and benign thyroid nodules. The study had been inspired by the well-known wide variation in the reported prevalence of the coexistence of chronic autoimmune thyroiditis with differentiated thyroid carcinoma.

A team of endocrinologists from Białystok, based on the results of their own studies, performed a critical analysis and comparison of the clinical usefulness of salivary cortisol measurements for the diagnosis of hypercortisolism. The study showed that measuring salivary cortisol levels is more useful in the investigation of subclinical Cushing's syndrome than measuring serum cortisol levels at $11 \mathrm{pm}$. Late night salivary cortisol also seems to be a valuable diagnostic criterion in the differential diagnosis of pseudo-Cushing's syndrome.

In another original paper, a team of three professors from Łódź discusses immunohistochemical detection of follicle-stimulating hormone receptors (FSHR) in neuroendocrine tumours. We already knew that FSHR are present in the gonads and tumours originating in the gonads. Recently, however, FSHR have also been identified in endocrine tumours, such as adrenal tumours and pituitary adenomas. The authors showed the presence of FSHR both in tumour cells and in certain tumour blood vessels of neuroendocrine tumours (NETs). A positive reaction to anti-FSHR was observed in the cytoplasm of most of the investigated NETs. Half of the investigated NETs also showed immunopositivity for FSHR in the endothelia of the tumour blood vessels. Interestingly, positivity for FSHR was observed more commonly in the blood vessels of tumours with higher Ki-67 values.

In another paper, the authors compared serum levels of prohepcidin and iron metabolism parameters 
in obese versus non-obese elderly individuals, as the current state of knowledge suggests that overweight and obesity are closely related to the disorders of iron metabolism, and hepcidin may be a significant contributing factor to iron deficiency seen in the population of obese individuals. The results confirmed the initial assumptions. Serum prohepcidin showed a positive correlation with body fat percentage in both obese anaemic patients and obese non-anaemic patients. It may therefore be concluded that the adipose tissue may affect serum prohepcidin levels and the systemic iron metabolism.

Iranian authors presented the results of the CASPIAN III study that assessed the results of an evaluation of the validity of a continuous metabolic syndrome score (cMetS) as a marker of metabolic syndrome in a national representative paediatric population of three thousand schoolchildren. cMetS seems to be an appropriate marker for use in epidemiological studies investigating the relationship between risk factors and the development of metabolic syndrome.

Authors from Turkey determined the prevalence of the variability in the number of copies of the KAL1, GNRH1, GNRHR, PROK2 and PROKR2 genes in male patients with idiopathic hypogonadotropic hypogonadism (IHH). Determination of the genetic background considerably deepens our understanding of this complex disease and may be useful in genetic counselling and developing the treatment plan. Furthermore, discovering associations between genetic mutations and IHH largely contributes to our knowledge on reproductive function.

The study presented in the next evaluated the levels of placental growth hormone (PGH), pituitary growth hormone (GH), IGF-1 and ghrelin in the umbilical cord blood serum and in the amniotic fluid in an attempt to find factors that would enable to predict neonatal development. The study showed a significant role of $\mathrm{PGH}$ in maintaining an appropriate pool of IGF-1.

In the Review Papers section, we would like to invite you to read an extremely interesting paper authored by experienced endocrinologists from Ohio University, USA. The paper provides a review of the current state of knowledge on disulphide bonds in the structure of growth hormone, as they affect the biological activity of GH both in healthy individuals and in patients with GH1 gene mutations.

The Case report in this issue has been authored by doctors from a diabetes facility in Silesia. The authors describe three women from the same family with the diagnosis of Dunnigan-type familial partial lipodystrophy, a very rare condition in clinical practice. The paper also has an extremely educational value, as it provides a detailed discussion of the aetiology, pathogenesis, clinical course, diagnostic evaluation and management.

The Postgraduate education section contains two papers. The first one, authored by our colleagues from Warsaw, is a comprehensive discussion of the clinical aspects of primary aldosteronism with a particular focus on the recent developments in the diagnosis and treatment of this condition. The second paper, of multicentre and multinational authorship, presents the current guidelines on vitamin D supplementation for Eastern European countries. The authors recommend using specific doses of vitamin $\mathrm{D}$ both in the healthy population and in the groups at high risk of vitamin $\mathrm{D}$ deficits.

We hope that you will find this issue of the Journal scientifically stimulating and useful for your clinical practice. 